\title{
Research on the Writing History of Arabic Rhetoric Studies and its Importance
}

\section{Roslan Ab Rahman}

\author{
Arabic \& Islamic Studies Department, \\ Faculty of Islamic Studies, National University of Malaysia \\ Email: roslana98@gmail.com
}

\section{Prof. Dr. Tengku Ghani Tg.Jusoh}

Arabic \& Islamic Studies Department Faculty of Islamic Studies, National University of Malaysia

Email: tgtj@ukm.my

\section{Md. Nor Abdullah}

Senior Lecturer, Arabic \& Islamic Studies Department Faculty of Islamic Studies, National University of Malaysia

Email:monab@ukm.my

\section{Hashim Mat Zin}

Department of Arabic Studies \& Islamic Civilization Faculty of Islamic Studies, National University of Malaysia UKM Bangi, 43600, Selangor, Malaysia.

Emel : hashimbes@yahoo.com.my

Doi:10.5901/ajis.2013.v2n9p517

\section{Abstract}

\begin{abstract}
Now the situation studies in Arabic Rhetoric in Malaysia, especially in the field of Islamic studies such as misinterpretation of the Quran were less emphasized. This problem may stem from a lack of knowledge disclosure Rhetoric since in school, higher education and society in general. Learning Arabic is mostly just focused on knowledge of grammar and morphology without involving Rhetoric. Therefore, the objective of this study is to make a review of the early history of the development of preIslamic Rhetoric again until the eighth century as exposure to entice the attention of the community to Arabic Rhetoric and explain its significance. Library research method chosen to obtain the necessary data from the book of Arabic Rhetoric tradition. As a result, it is evident that the persistence of the scholars of the past do a research field with many other Arab Rhetoric inject motivation to researchers now. Leading works by al-Jurjani has opened a new dimension to the theory of Arabic Rhetoric al-Nazm (diction is the choice of words and sentence patterns appropriate to the situation). Its importance is very helpful to understand the Quran better.
\end{abstract}

Keywords: History of Arabic Rhetoric, Arabic Rhetoric and The importance of the Arabic Rhetoric.

\section{Preliminary}

Knowledge of Arabic Rhetoric has its own historical development. Basically, it goes back to before the Quran decline as time goes by uncivilized time is, famous for its progress in terms of Arabic literature such as poetry and so on. Criticism Arabic language and literature, including aspects Rhetoric is also discussed by the great Arab Literary Man including their own poetry Rhetoric value of its own. Put simply the starting point and the historical development of Arabic Rhetoric is very interesting to follow because to have originated in uncivilized times more before the birth of Islam.

\section{Writing Arabic Rhetoric}

Rhetoric refers to the development as it has been tried, have been concluded, a sign of knowledge is the existence of 
Rhetoric began literary criticism among Arab writers. When poetry or prose submitted by the poet or orator in a meeting, it will be evaluated and criticized orally by great writers of the time. While aspects of this study also writing Rhetoric put time guidelines centered on leading figures in Arab Rhetoric of al-Jurjani. This is because he has agreed scholars that his time is past glory and perfection Rhetoric. Thus, the starting point and the peak of knowledge can be described matriarchal Rhetoric time round and the actual situation can be highlighted Rhetoric travel knowledge.

\section{Writing Arabic Rhetoric Before 'Abd al-Qahir al-Jurjani (Growth Era)}

According to the scholars of al-Azhar University Rhetoric of 'Abd al-Sattar Husain (1991:24) hopefully accurate assuming views scholars leading language Sibawaih Basyar the real name of Abu' Amr ibn 'Uthman (d.180H) is the earliest writer on Arabian Rhetoric. It is seen as a precursor though he wrote in his famous methodology based on Arabic grammar so called "Qur'an al-Nahwi". In fact, between content writing is about "al-Taqdim wa al-Ta'khir" (Precede \& Finalize), "alDhikr wa al-Hadhf" (Say \& Remove) and so the actual topics also between content knowledge al -Ma'ani according to the scholars of Arabic Rhetoric date. Although topical Sibawaih not written like al-Ma'ani knowledge, it was also his writing contains a debate about al-Bayan knowledge as Tasybih, Isti'arah, kinayah and others. Similarly, the availability of the debate about the science of al-Badi '. After Sibawaih then appear Abu 'Ubaidah bin Mu'ammar al-Muthanna (d.206H).

As for according to Mahmud al-Sayyid al-Syaikhun (1983:5-6) states that the earliest writing Rhetoric can be detected is the knowledge al-Bayan by Abu 'Ubaidah bin Mu'ammar al-Muthanna (m.206H) through his book "Majaz AlQuran "(Quranic Miracle). The cause of writing this book is to answer the questions posed by Ibrahim bin Ismail, a writer while in the Ibn al-Rabi 'a governor of Basra at the time of the Caliph al-Ma'mun ibn Harun al-Rashid (d.218H) . The question is, and given to him is about Zaqqum tree mentioned in the Qur'an:

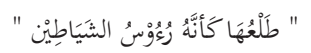

That is, "as if head pendant devil". (Surah al-Saffat, 37:65) The text uses the language style in comparison thinly Tasybih Zaqqum tree with devil head but it is not known by anyone about his condition. This is a questionable thing to Abu 'Ubaidah. Thus, he brings a poetic stanza Umru 'al-Qais related to this issue:

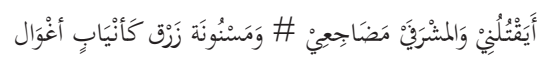

That is, "Is he going to kill me when sword and a sharp eye my lance canine goblin like pillows made? Arguments Abu 'Ubaidah said that parable ranks higher (subject or set the benchmark for the canine goblin comparison) in the poem is also not known anyone. But the purpose of this comparison is to make a picture comparison (subjects compared with other materials that sword and spear) with a bad impression and scare people. After debating this issue, Abu 'Ubaidah start writing with a lot of words in the Quran that brings the spirit and not the original meaning. Works that are meant for the title "Majaz al-Qur'an", as stated by Fadl Hasan 'Abbas (1998:71) that this book is actually a lot of debate focused on language and linguistics, but the debate surrounding the science of rhetoric "albayan"(comparison,metaphor \& symbolic) is also found in the discussion. Majaz al-Qur'an is the way to achieve understanding of the meaning of the Quran. With that Abu 'Ubaidah took the initiative real (Haqiqah) explanation for the style of language (real) and not a chapter-by-chapter real. Therefore, he considers Abu 'Ubaidah was the trigger writing about science group "al-Bayan".

According to 'Abd al-Sattar Husain (1991:25-28) again, after that came the al-Jamahi (d.232 H) has compiled a book called "Tabaqat al-Syu'ara'" (Group of Poets). Content is about learning Arabic literary criticism and there are also many debates about Rhetoric.

Then came al-Kinani son lover, nicknamed as al-Jahiz the black eye looks quite big and he was born in Basra in the year $150 \mathrm{H}$ and died in $255 \mathrm{H}$. Writing his famous book is "al-Bayan wa al-Tabyin". According to Taha Husain, al-Jahiz considered the founder of knowledge al-Bayan al-'Arabi real.

Syauqi Daif (1965:22) also says no exaggeration to al-Jahiz considered the founder of Arabic Rhetoric through the production of his book "al-Bayan wa al-Tabyin", "al-Hayawan" and "Nazm al-Quran". His book is a lot of talk about the Rhetoric with a variety of design examples from the field of knowledge whether Meanings (al-Ma'ani), al-Bayan or Maching Word (al-Badi'). 'Abd al-Sattar Husain (1991) also acknowledged that Al-Jahiz also talk about al-ljaz (short), ie the opposite to al-Itnab (decomposition) and al-Italah (lengthening). Similarly, he discusses aspects of al-Takrar 
(repetition). Mostly relied on its use in the Qur'an. While in terms of al-Badi ', found him to talk about it in general terms as the al-Saj', al-lqtibas and so by giving meaning and example.

Thus it can be concluded that between the writing and the efforts of al-Jahiz in the field of Arabic Rhetoric as matters of pronunciation and speech as an important tool in public speaking. This is the source of al-Bayan beauty that should put every fonetic reference letters properly. Completion of pronunciation and fluent tongue, and avoiding defects are areas of concern voice. "Fluent Word" and "Fluent Convesatioan" has also been tried by him. He also emphasized "Muqtada al-Hal"(According to the Situation) because every place and situation with the availability of an appropriate expression. Similarly, the selection of words coincided with what was intended. This is related to al-Ma'ani knowledge. As for the debate on knowledge of al-Bayan, he discusses at length about Comparison, Metaphore and Symbolic. His titles include within this chapter Language Miracle (al-Majaz al-Lughawi) or Metaphor. (Al-Jahiz, 1968)

According to 'Abd al-Sattar Husain (1991:28) again, then came the Ibn Qutaiba (d.276H) compiled two books which is called "al-Syi'r wa al-Syu'ara"' and "abstruse Quranic explanation". He explained the need to emphasize the importance of social status of the listener and the expansion of literary knowledge. With this, he highlights the art in chapter consise (ljaz) Rhetoric as requiring an examination of the language style.

Next, Ibn Yazid al-Mubarraad (d.285H) has compiled a book entitled "al-Kamil". He was locating pious including literature because according to another report, he memorized many literary texts such as poetry, and discuss the words and sentence structure as its ability. Although the essay is mainly concerned with aspects of language, grammar and literature, he also debated aspect Arabic Rhetoric as Comparison, Metaphors, Symbolic, Parable. In addition, he has also made criticism on the poetry of the famous temple in the words of the poet, Al-Farazdaq. (Ibid: 29)

A contemporary of al-Kufah Mubarrad the figure of the knowledge of grammar and language in the name of Abu al'Abbas Ahmad ibn Zaid. He was known to Tha'lab (d.291H) have authored a book titled "al-Syi'r Qawa'id" (Rule Poem). Content generally is about learning criticism, grammar and Rhetoric. (Ibid: 31) Then Ibn al-Mu'taz (d.296H) compiled a book called "al-Badi "' Rhetoric calculated the earliest books. The book is organized to address issues at the time of alBadi 'and other forms of Rhetoric. The book is also a source of reference to scholars such as Qudamah Rhetoric after Ja'far bin Abu Hilal al-'Askari and al-Amidi. The book 'al-Badi'has also become the most important source for Ibn alRasyiq for his book "al-' Umdah" (Headman).

While Abu Hilal al-'Askari (d.395H) has compiled two books of the title "al-Sina'atain" and "al-Kitab wa al-Syi'r". Debate in his book is filled with the explanation of the types of Rhetoric is divided into ten chapters and fifty-three chapters in all. Among them is like, a description of the etymology of Rhetoric, admirable and reprehensible speech differences, the order of speaking is wonderful, al-ljaz (brief) and al-ltnab (parsing), the source of good drawings, comparison debate, al-Saj '(beauty rhyme end) and word pairs, matching word and the description of the word syllables. (Ibid: 32)

Obviously, al-Sina'tain book is a book of literary criticism, and it includes criticism of matters relating to the Rhetoric. There is a view that he has brought the form of literary criticism in teaching Rhetoric. He also relied heavily on the book by predecessors like "Tabaqat al-Syu'ara "' by Ibn Salam al-Jamhi, "al-Bayan wa al-Tabyin" by al-Jahiz, "alBadi"' by Ibn Mu'taz and others. Writing about continuing with the advent of Arabic Rhetoric Abu Bakr Muhammad alTayyib al-Baqillani (d.403H) through his book titled "l'jaz Quran" (miracle of Quran). He makes big role in terms of Rhetoric and the miracle of Quran free from any criticism of a censure against him.

In conclusion, this time to disclose the availability of new disciplines in the development of Islamic civilization in the Arab Rhetoric. But in this day and age a lot of discussion mixed with science debate as Sarfah (human weaken rival god Quran), unseen and storytelling of previous peoples. In other words, when the debate on knowledge Rhetoric is often associated with the question of the Islamic faith to be an issue at the time. As if the debate about Arab Rhetoric not be a specific debate. However, from the point of obvious importance to prove that the Quran is indeed is unmatched by any other Arab writers to prove l'jaz and supremacy of the Quran itself.

\section{Writing Balaghah Ages al-Jurjani (Ages Perfection \& Excellence)}

According Syauqi Daif (1965:160) study of Arabic Rhetoric knowledge has reached perfection and glory during the fifth century Hijri. This is because knowledge Rhetoric has had its own terminology system and the complete writings. This golden era including l'jaz knowledge of the Quran because it parallel with the development of Arabic Rhetoric itself.

According to 'Abd al-Sattar Husain (1991:34), al-Qairawani (d.463H) wrote a book titled "al-'Umdah Sina'ah fi alSyi'r Naqdih wa ". He actually collect and quote the eyes of scholars' previous Rhetoric in matters of criticism and Rhetoric. Therefore, not surprising that era of his books became an important reference by other researchers Arabic Rhetoric until now. In addition, the book by al-Jurjani that appeared eight years later. 
Next appeared al-Khafaji (d.466H) who wrote a book titled "Sirr al-Fasahah" (Secret Fluency). The content is defending arguments about Quranic Rhetoric become an important contributor to supremacy of the Quran. He was preceded in Motion restructuring Balaghiyyah (fundamental debate Rhetoric) Rhetoric science debate on the order of many contemporary writers talk about Fasahah and Rhetoric al-Kalam. Apparently, from the book "al-Fasahah sirr" writers from the beginning to try title and has stated that two main conditions to be maintained in order sentences. Firstly, avoid Tanafur al-letter (sounds awkward letters) of a word mentioned difficulties caused by the order of the letters. He requires the word to be of the order of letters away from makhraj position. He said the sound out each letter as a reference to the role of hearing and eyesight color to each image when attached brightly colored and clearly visible better than grafts colored image matching. Thus its pronunciation similar letter will definitely tough call. Secondly, he mentioned the word in a sentence should not be foreign and commonly used.

In conclusion, when looking at the book the author talks about the latest Fasahah al-Kalam (Speech Fluency), Rhetoric al-Qaul (words) and the parallel situation shows that it is the influence brought by al-Khafaji in writing legacy of "sirr al-Fasahah "(Secret Fluency).

After al-Khafaji, these scholars' Rhetoric distinction which opens new dimensions in knowledge. He was al-Jurjani (d. $471 \mathrm{H}$ or $474 \mathrm{H}$ ) leaving two valuable books on the "Asrar al-Balaghah" (Rhetoric mysteries), " Dala'il al-l'jaz " (miracles arguments).

Both serve as a reference in the study of Arabic Rhetoric until now. Between theory and things triggered through his book is as follows:

1. Differentiate between types of simulation with clear limitations.

2. Clarifying words (al-qaul) by naming theory al-Nazm (word order), and the scholars' recent naming of al-Ma'ani knowledge.

3. Research carefully in revealing the true source of beauty and the imbalance of words.

4. The strength of literary spirit with an exciting style language with accompanying texts that were analyzed with the tastes and feelings. (al-Jurjani, 1998)

In short, al-Jurjani open a new dimension in the study of Arabic Rhetoric with two important underlying theory, called al-Nazm. Firstly, using language appropriate to the situation or context. Both use the language fluently and clearly.

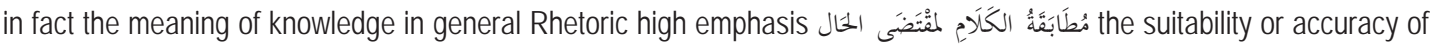
the conversation with the situation or context of things. In other words, the text to be used in speech or writing should be parallel with the existing situation that purpose or the message can be delivered more effectively against a listener or reader. The matter was settled by al-Jurjani (1988:41) describe the method in the arrangement and structure of sentences with the words:

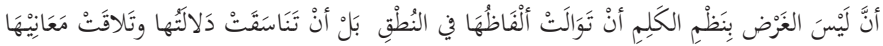

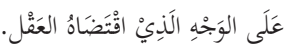

That is, "It's not the purpose of the set so that consecutive sentences said the mere mention, but hopes that the inter-linking means that in line with the pronouncement of mind".

Rhetoric refers to the study of al-Jurjani also appears to discuss his argument begins with the concept of sentence structure grammar prior knowledge and its relation to meaning. Then he discusses the question of words and meanings associated with al-Ma'ani knowledge. 'Abd al-Sattar Husain Zamud (1991:38) also recognizes the important things in the field of Arabic Rhetoric at the time of' al-Jurjani in the fifth century is still divided into three components Rhetoric knowledge, namely knowledge of al-Ma 'ani, al-Bayan and Al-Badi'. Even the debate is still under various names such as al-Balaghah, al-Fasahah, al-Bara'ah, al-Badi 'and al-Bayan.

Fath Ahmad Amir (1975) has written issue of al-Nazm idea by al-Jurjani this in his book. He attributed this idea alNazm miracle form part of the Quran al-Karim. Tabanah Badawi (1958, p: 200) has been added to clarify the appropriateness of this situation is in fact to be an important prerequisite to the three parts of the knowledge Rhetoric alMa'ani knowledge, al-Bayan and Al-Badi '. If a sentence using the word and its meaning was interesting but did not refer to this requirement, sentence or phrase is still considered incomplete in the sense that the actual meaning of the Rhetoric of knowledge.

This debate is also discussed by Ibn Khaldun (w.y: 550) which is to obtain a perfect delivery meaning it cannot be based on aspects of grammar (grammar and morfologi) only, but the approach should also look into the appropriateness of stylistic aspects of the situation listener. This is because of the privilege of the Arabic language is every situation has a 
specific stylistic approach him. Through his views, it can be concluded that the study of the Arabic language would not be complete without involving knowledge as well as knowledge of grammar Rhetoric.

In conclusion, the comprehensive work by al-Jurjani has introduced the theory of al-Nazm diction is the choice of words and sentence patterns that fit the foundation in Arabic Rhetoric whether al-Ma'ani knowledge, al-Bayan or al-Badi '. Her age is considered as the golden age of Arabic Rhetoric although not yet exist division three components separately. But what is important is his approach always associate each expression with grammar methodology, knowledge of alMa'ani, al-Bayan and Al-Badi '. Not like that has not happened earlier, that only after structured in a manner that brings with it.

\section{Writing Arabic Rhetoric After al-Jurjani (Fatigue Era)}

Continuity writing Rhetoric field after al-Jurjani era adopted by al-Zamakhsyari (1987), (d.538H) by writing commentary called "al-Kasyyaf 'an Haqa'iq al-Tanzil wa' Uyun al- Aqawil Wujuh al-Ta'wil fee ". At the beginning of this commentary book he mentions important thing for everyone to explore, the interpretation of the Quran is the control of the two branches of knowledge that al-Ma'ani and al-Bayan. This is clearly seen through his words:

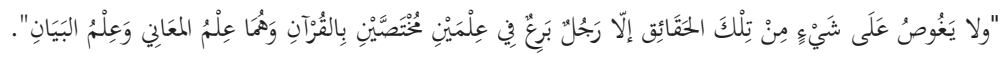

Meaning, "One could not penetrate a fact (the Qur'an) but a man who truly proficient in two specific knowledge with knowledge of the Qur'an al-Ma'ani and al-Bayan". This item references separately calculated for the first time for both knowledge after al-Jurjani. Therefore, it is understood that the segregation specifically in Rhetoric debate has begun to appear on the statement by al-Zamakhshari. But what is important, this can be proved that the knowledge is closely interlinked with each other and cannot be separated in discussing Rhetoric Quranic verses, and is in line with what has been taken by al-Jurjani. In fact, treatment of the Quran verses interpretation in terms of its language was inseparable from the concept of knowledge al-Ma'ani and al-Bayan because this basis that will produce outcomes that are targeted in any related studies.

In short, the theory brought by al-Jurjani was practiced by al-Zamakhsyari through misinterpretation of known alKasysyaf. Although al-Zamakhshari said Mu'tazili faiths, but agreed that its interpretation of scripture scholars of Ahlus Sunnah wa al-Jamaa'ah as authentic interpretation. The proof is recognized by al-Suyuti (w.y, Vol.1: 21), which made it clear tafsir al-Kasysyaf is one of the key reference books in the completion of his book, "al-Itqan fi 'Ulum al-Quran". AlSuyuti and al-Mahalli (1987) in the narration of "Tafsir al-Jalalain" also clearly state the name of al-Zamkhsyari at number three in its list of fourteen scholars of tafsir famous they refer. List queries are al-Tabari, Ibn Kathir, al-Zamakhshari, alQurtubi, al-Razi and others. Besides the aspect of figh and hadith Al-Suyuti (1987) also recognizes the scholars' emphasis on aspects of language interpretation, and Rhetoric l'rab as tafsir al-Kasysyaf by al-Zamaksyari.

After al-Zamakhshari, came the Fakhr al-Din al-Razi (d.606H) through his book entitled "al-ljaz Nihayah Dirayah alI'jaz fee". This book is a summary of the studies purporting to al-Jurjani but also many other books that are based on common sense (' aqliyyah) and not writing al-Jurjani. Obviously, al-Razi wrote Rhetoric with style language scholars' knowledge of al-Kalam (monotheism). Thus, he opposed the restructuring of Rhetoric by scholars prior to the "Manhaj Adabi" (literary discipline) but he started a new way called the "Manhaj philosophical" (discipline of philosophy). Among the significant differences between the two disciplines is through Manhaj philosophical, it is concerned with the question of the proper definition, distribution and limitations and lack of examples of titles and literary evidences like poetry. While Manhaj Adabi is the lack of debate about definitions, rules and division of topics and extensive use of examples and evidences such as poetry and prose literature. Adabi Manhaj privileges are accessible language style and does not need to work hard to understand. ('Abd al-Sattar Husain Zamud, 1991:40)

Then came the scholars called al-Sakkaki (Abu Ya'qub Yusuf ibn Abi Bakr) (d.626H) who wrote a famous book called "Miftah al-'Ulum". Rhetoric knowledge was placed at the third and he divides into three main sections. First debate about Arab pronouncement of aspects of the situation and naming consistency with knowledge of al-Ma'ani. Secondly, the debate about words in terms of guidance and called with knowledge normally al-Bayan. Third, the debate about words in terms of glamor and glitter, then refer to it as "Muhassinah" the category now known as science al-Badi '. (AlSakkaki, 1937)

Next, Badr al-Din Ibn Malik (d.686H) wrote a book called "al-Misbah" continues three-part naming Rhetoric from early writings further with al-Ma'ani knowledge, al-Bayan and Al-Badi '. Such slip bands naming the three parts, firstly by al-Zamakhshari and executed by al-Sakkaki and Badr al-Din Ibn Malik. After the al-Sakkaki, birth compile many of his 
famous book Rhetoric and al-Khatib al-Qazwini (d.739H) to summarize the book "Miftah al-'Ulum" in a material called "Talkhis al-Miftah". Then he wrote the book "al-waiting period fi "Ulum al-Balaghah" as a sermon for the material. (Ibid, p: 42) This book is also a focus of debate after the masters to the modern age. Among scholars such as Muhammad 'Abduh (m.1905M), Hafni Nasif (d.1919M), Ahmad al-Hashimi (m.1943M) book "Jawahir al-Balaghah", "Ali al-Jarim (d.1949M) with his famous among students nowadays Rhetoric of "al-Balaghah al-Wadihah", Ahmad Mustafa al-Maraghi (d.1952M) with his "'Ulum al-Balaghah" and Amin al-Khuli (d.1966M) with his "Manahij Tajdid wa fi al-Tafsir al-Balaghah".

While the term components such as al-Ma'ani Rhetoric, al-Bayan and Al-Badi 'first adopted widely. Title in knowledge Rhetoric as al-Qasr, al-Fasl wa al-Wasl, Al-Tasybih (simile, al-Isti'arah (metaphore) and others also discussed in detail. Books are affected Dala'il al-l'jaz, Asrar al-Balaghah by al-Jurjani and al-Sina'atain by Abu Hilal al-' Askari. The third type is the work of academic Rhetoric. This work brings knowledge Rhetoric structured with rules. Through the work of this kind of knowledge Rhetoric apparent division into three main sections al-Ma'ani knowledge, al-Bayan and Al-Badi '. Among the works of this kind such as books Miftah al-'Ulum al-Sakkaki, summary of the book al-Talkhis and commentary to al-waiting period by al-Qazwini.

As according to Balkis Abu Bakar (1999), as a whole before the Rhetoric of knowledge organized as a form of discipline knowledge, Rhetoric works can be divided into three types. Firstly, the work of the literary form of writing Rhetoric disclose discussions of knowledge and it is stated in the books of tafsir or literature such as books al-Bayan wa al-Tabyin by al-Jahiz and Majaz al-Qur'an by Abu 'Ubaidah. Debate both seen the book focuses on Rhetoric indirectly, but it mentions about term, type and Rhetoric problems. The second type is a form of literary works that are in it elements of Rhetoric. Rhetoric of this kind bring in more scientific elements. Literary texts are discussed and analyzed based on the knowledge of Rhetoric.

In conclusion, the growth of travel and writing knowledge of Arabic Rhetoric become a valuable repository of knowledge. Everything is left to be basic and essential reference source in the study area of Rhetoric. Can be seen also persistence of the scholars' Arabic Rhetoric in the study of their work according to their own approach. However, what is important is perfection Arabic Rhetoric disciplines have been achieved through an idea with scholars who work with full trust for the sole purpose of proving the majesty and glory of the holy book of the Qur'an in particular aspects of the language style placement and appropriately according to the situation. Although the post al-Jurjani considered fatigue as the only forward only what has been founded by him, but the study of Rhetoric in general continues to grow from time to time until now.

This study is a continuation claim further research in the field of Rhetoric Quran especially the analysis based on the Quranic verses Rhetoric disciplines that already exists. Although such studies have been in existence in the world of Rhetoric study the Quran, especially in Malaysia or anywhere, but preferably should bring intensified by all Muslims or non-Muslims. Such efforts calculated to assist in the process of understanding the Quran in depth. Indirectly Rhetoric interests will be able to more clearly highlighted.

\section{Knowledge of the Importance of Arabic Rhethoric}

No doubt that every science has its own interests include knowledge Rhetoric. Therefore, before discussing about any style of language in the Quran in detail, must first look in terms of importance and purpose of learning Arabic Rhetoric itself. After looking at the development or growth of Arabic Rhetoric to develop as a discipline of knowledge, it was appropriate to be learned by every Muslim Rhetoric of knowledge is considered to be the key to knowing the secret supremacy of the Quran, especially in the use of a particular language style that proved unmatched by anyone. Drawn Iqbal Sheikh Saleh (1999:13) in his study related language style of the Qur'an has stated that Rhetoric is important to learn Arabic together with other components. This is because with a deep understanding of Rhetoric knowledge will help one understand the secret supremacy of the Quran and the meaning of its contents in detail.

Importance of Rhetoric more prominent when associated with stylistic excellence of the Quran in Arabic. According to Ahmad al-Sya'ib (1991:17) who discuss the importance of language style state stylistics very important because they provide significant benefits to the writers, critics, historians, authors, speakers and teachers. He added that with the knowledge that language style that make a good speech and a great person as well as attracting the attention of the listener and deeply affected.

With this explanation can be stated that the study of language style is appropriate aspects followed by every Muslim in order to achieve the understanding of a text with a thorough and comprehensive. Especially in order to understand the verses of the Qur'an which is the great miracle of the Prophet Muhammad to guide Muslim life. In essence, that the study of Rhetoric knowledge of the Quran is interested in general and the specific. 


\section{The Importance of Balaghah General Studies}

Generally studies in Rhetoric definitely has its own causes and interests. Based on opinion Ahmad Matlub (1973:32) mentions that there are three major factors of interest or to pursue the Arab community.

Firstly, the importance of the religious aspect as a service to the study of the Qur'an which is required by the Prophet Fada'il his saying in the chapter of the Qur'an:

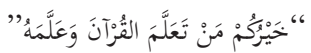

Meaning: "The best of you are those who learn the Qur'an and teach it too." (al-'Asqalani, 1986, Vol.13: 393) When knowledge learned Rhetoric and stylist should be made of the study will help in the understanding of the Quran in depth especially through language style used. By itself the greatness and supremacy of the Quran could be clearly disclosed.

Secondly, the importance of the teaching aspect to avoid defects occur widely in Arabic because Arabs mixing and interaction with other people, work to be done and extended teaching. For this purpose, the Arabs began to pursue his studies for contributing to the problem.

Furthermore, other Arab nations is indeed in dire need of guidance in Rhetoric studied to assist in understanding the contents of the Quran in depth.

Thirdly, the importance of critical aspects of the development of literary criticism based on Arabic as spoken, clear role Rhetoric knowledge as a guideline to make criticism of the critic in a text. Rhetoric is also regarded as a benchmark in determining the deficiency and excess of a text.

\section{The Importance of Specific Balaghah Studies}

Based on three studies of general interest, the religious aspect should be more preferred than others. because it can meet the needs of all segments of society. It argues about the language style of the Quran which is a major contributor supremacy of the Quran from aspects. The Qur'an also as a source of primary law and guidelines of life for all Muslims. Hence, the importance of more specialized studies Rhetoric is focused on al-Quran and al-Hadith.

Firstly, to help in the fight deeper stylistic beauty of the Quran and learn the secrets of its miracle. According to Osman Khalid (1987:160), in fact, the content of the Quran miracle itself is on the beauty and dynamism of the language used and the arrangement of stylistic prowess. It will not be matched by any human works or to resembling it. Subhi alSalih (1978:46) states that there are verses in the Qur'an which gives open challenge to the unbelievers who consider the Quran is part of the treatment of poetry and magic. This issue was discussed in the topic "Balaghah the beginning, Islam", where God has opened these challenges through his word in the Holy Quran.

According to al-Khafaji et.al (1988:118) when surveyed, it appears Rhetoric of the Quran bring new elements in addition to the existing ones. However, it is not meant Rhetoric of the Qur'an out of style and language commonly used methods such as al-Qasr (devoted to something else), al-Taqdim wa al-Ta'khir (advance and end), al-Tasybih ( comparison simile) and others, including al-Inab. However, the Qur'an has to elevate to the level of use of Rhetoric is greater than normal use and that is a l'jaz element of the Quran to be tried in more detail.

Al-Maraghi (1950:56) notes that self-knowledge Rhetoric help in expressing their beauty features of the Quran and explain the secrets contained in a form of language style used. This is particularly noticeable through language style debate, meaning the delivery method and the various forms of expression in the Quran than what is used in Arabic poetry and prose works of ordinary people.

In conclusion, it appears Rhetoric importance of the Quran as an impact that is useful to the Muslim community in particular. Looking at the efforts of the scholars' Arab Rhetoric like that has been tried already clear to us that it is necessary also to every Muslim as well as knowledge of grammar study and morporphology although the basic level only. At least able to recognize and embrace a stylistic approach used in the Qur'an.

Secondly, understand the greatness of Hadith language style Prophet word of Allah s.w.t:

$$
\text { " ومَا يَنْطِقُ عَنِ الموَى . إنْ هُوَ إلَّاَ وَحْيُ يُوْحَى ". }
$$

That is, "And it does not say (something related to Islam) of his own and his own opinion. Indeed it is (either the Qur'an or Hadith) is nothing but revelation that is revealed to him. "(verse al-Najm (53) :3-4. Based on the word of God is 
evidently what is uttered by the Prophet is also the revelation from God, and it is a source of reference both for Muslims after the Qur'an. With Rhetoric studies also contained fasahah secret in Arabic poetry and prose can be followed by those studying Rhetoric. At least good and bad expressions can be distinguished and by itself will show an expression of the greatness of Rhetoric. (al-Hashimi, tt: 38)

Rhetoric Review hadith by Abdul Rahman Mohd Shukri (2010), entitled "Analysis Isti'arah In the Book of Riyad alSalihin" show text study hadith done using various forms of use Isti'arah style accordingly. As a result, the meaning of the hadith can be communicated clearly, away from the elements of coercion and confusion, and Jawami' elements of 'alKalim (Compatibility words). While the results of the field study of society to pursue their scriptures in mosques in Malaysia found Isti'arah theoretical contribution in this hadith significant effect in appreciation of the meaning of this hadith among the respondents.

In conclusion, knowledge is indeed very necessary Rhetoric as help in the understanding of the meaning and deepen sign language style of the Quran or al-Hadith. With this knowledge skills and the uniqueness of the language style of the Quran and al-Hadith will be highlighted and the implied meaning will be clarified. In turn, will help a person to understand a text of the Quran or al-Hadith in depth and full appreciation.

\section{Conclusion}

Writing time before al-Jurjani generally does not separate the three components Rhetoric. Debate Rhetoric knowledge when it is often associated with the question of the Islamic faith to be an issue at the time. As if the debate about Arab Rhetoric not be a specific debate. Ideology that denies al-Sarfah l'jaz element of the Quran with the belief that God (Allah s.w.t) turned his gaze from the first Arab writers create such works of the Qur'an even if they can do it. Al-Jurjani to approach the three components tighten Arabic Rhetoric without isolating specific chapter. He introduced the theory of alNazm diction is based on the selection of words and sentence patterns are appropriate. This is his time considered the golden age of Arabic Rhetoric although not yet exist division three components separately. But what is important is his approach always associate each expression with grammar methodology, knowledge of al-Ma'ani, al-Bayan and Al-Badi '. Not like that has not happened earlier or later arranged a perfect separation of the three components, but just continue the way it presents.

Arabic Rhetoric disciplines perfection achieved through a pool of scholars who work with full trust for the sole purpose of proving the majesty and glory of the holy book of the Qur'an in particular aspects of the language style placement and appropriately according to the situation. Although the post al-Jurjani considered fatigue as the only forward only what has been founded by him, but what's important study of Rhetoric in general continues to grow from time to time.

Expected persistence idea scholars Rhetoric become the world motivation to study injection Rhetoric in Malaysia. This study strongly supports the study of the language style of the Qur'an as al-Insya 'in Surah al-Nur (Siti Ikbal Sheikh Saleh: 1999), Isti'arah in Surah al-Baqarah (Ab Rahman Roslan: 2005) and repetition of the Verser Al-Rahman (Zahazan Mohamed: 2011). Such studies are very desirable pursued by researchers, especially in Malaysia to research transformation Rhetoric of the Qur'an can be increased from time to time and consequently every revelation of God can be understood more deeply and can be appreciated better.

In short, the Quran Rhetoric has its own role to the Muslim community in particular, especially in the deeper verses of the Quran. In addition to grammar and morphology subject, the subject of the Quran Rhetoric should be extended at various levels and in line with the level of education according to the suitability of Quran's explanations and hadith. Every Muslim should learn at least be able to recognize and appreciate the variety of interesting stylistic approach used in the Quran or al-Hadith. As such, the study will be more exciting and fun.

\section{References}

Al-Quran and Translation,(W.Y), Majma 'Khadim al-Haramain, Medina: Tiba'ah al-Mushaf al-Sharif.

'Abd al-Qahir al-Jurjani (1998) Dala'il l'jaz fi al-' Ilm al-Ma'ani, Editor: al-Sayyid Muhammad Rashid Rida, Beirut, Dar al-Ma'rifah.

'Abd al-Qahir al-Jurjani, (1989) Dala'il al-l'jaz, Cairo, Ed..2, al-Khanji Maktabah.

'Abd al-Sattar Zamut Husain, (1991) Muhadarat fi Tarikh al-Balaghah al-' Arabiyyah, Cairo, al-Lughah Kulliyah al-'Arabiyyah, Jami'ah alAzhar.

Ahmad al-Sya'ib, (1991), al-Uslub, Cairo, al-Nahdah Maktabah al-Misriyyah.

Ahmad Matlub , (1973) Manahij Balaghiyyah, Kuwait, al-Matbu'ah Wakalah Sa'adah Jami'ah Baghdad 'Ala Nasyrih.

Al-Jahiz, Abu 'Uthman' Amr ibn Bahr, (1975) al-Bayan wa al-Tabyin, Cairo, Vol.1, Ed.4, Maktabat al-Khanji.

Al-Maraghi, Mahmud Ahmad Hasan, (1991) 'Ilm al-Badi', Beirut, Dar al-'Ulum al-' Arabiyyah. 
Al-Sakkaki, (1937) Miftah al-'Ulum, Cairo, Matba'ah Mustafa al-Babi al-Halabi wa Auladih)

Al-Suyuti, Jalal al-Din \& Al-Mahalli, Jalal al-Din, (1987) Tafsir al-Jalalain, Cairo, Dar al-Rayan.

Al-Zamakhshari, Mahmud ibn 'Umar, (1987) al-Kasysyaf' an Haqa'iq Ghawamid al-Tanzil wa 'Uyun al-Aqawil Wujuh fi al-Ta'wil, Vol.1, Cairo, Dar al-Rayan li al -Turath,

Tabanah Badawi, (1958) al-Bayan al-'Arabi: Dirasah Tarikhiyyah Fanniyyah Balaghah fi Usul al-al-' Arabiyyah, Ed.2, Cairo, al-Anglu Maktabah al-Misriyyah.

Fadl Hasan 'Abbas, (2009) l'jaz al-Quran al-Karim, Amman Jordan, Ed.7, Dar al-Nafa'is.

Fath Ahmad, Amir (1975), Ideology bain al-Nazm al-l'jaz Wujuh fi al-Quran al-Karim ", Cairo, al-A'la al-Council-Syu'un li al-Islamiyya al. Ibn Hajar al-'Asqalani, (1986) Fath al-Bari bi Syarh al-Bukhari, Cairo,Vol.al-Muqaddimah, Matba'ah Mustafa al-Babi al-Halabi.

Ibn Khaldun, 'Abd al-Rahman ibn Muhammad, (W.Y). Muqaddimah, Cairo, vol.1, Ed.5, Dar al-Kitab al-'Arabi.

Ibn Rasyiq al-Qairawani, (1988), al-'Umdah fi Syi'r Mahasin al-wa wa Adabih Naqdih, Beirut, Vol.1, Dar al-Ma'rifah.

Ibn Salam al-Jamahi, Muhammad bin Salam, (TT) Fuhul Tabaqat al-Syu'ara ', Egypt, Vol.1, Matba'ah al-Madani.

Mahmud al-Sayyid al-Syaikhun, (1983) al-Balaghah Wafiyah li al-Saff al-Awwal al-Thanawi al-Azhar University, Cairo, al-Kulliyat Maktabah al-Azhariyyah.

Muhammad 'Abd al-Mun'im al-Khafaji,' Abd al-'Aziz, Ali Subhi and' Abd al-'Azim Syabla, (1988) Mu'jizah Quran al-' Usur, Cairo, al- Hai'ah al-Misriyyah al-'Ammah li al-Kitab.

Osman Khalid, (1987) Arabic Literature at the beginning, Islam, Kuala Lumpur, Publishing al-Nadhi.

Subhi al-Salih, (1978) study of the Qur'an, Translated by Zainal Abidin Abdul Kadir, Kuala Lumpur, John Wiley \& Sons.

Syauqi Daif, (1965) al-Balaghah: Tatawwur wa Date, Cairo, Dar al-Ma'arif.

Abu Bakar Balkis, (1999) Some Human Resources Knowledge Balaghah al-Ma'ani, al-Bayan al-Badi ', Proceedings of the Seminar on Arab-Malay Balaghah, Bangi, Department of Arabic and Islamic Civilization Studies, National University of Malaysia.

Ab Rahman Roslan, (2005) Isti'arah In Verse al-Baqara: An Analysis Balaghah, Kuala Lumpur, Masters Dissertation Faculty of Languages and Linguistics, University of Malaya.

Sheikh Saleh Siti Iqbal, (1999) Analysis of Language Style al-Insya' In Verse al-Nur, Kuala Lumpur, PhD Thesis, Faculty of Languages and Linguistics, University of Malaya.

Abdul Rahman Mohd Shukri, (2010), Analysis Isti'arah In the Book of Riyad al-Salihin, Kuala Lumpur, PhD Thesis, Faculty of Languages and Linguistics, University of Malaya.

Zahazan Mohamed, (2011) Style Language Repetition in the Qur'an: A Study In Surah al-Rahman, Kuala Lumpur, PhD Thesis, Faculty of Languages and Linguistics, University of Malaya. 